\title{
Potential of Macrocheles species (Acari: Mesostigmata: Macrochelidae) as control agents of harmful flies (Diptera) and biology of Macrocheles embersoni Azevedo, Castilho and Berto on Stomoxys calcitrans (L.) and Musca domestica L. (Diptera: Muscidae)
}

\author{
Letícia Henrique Azevedo $^{\mathrm{a}, *}$, Murilo Prudente Ferreira ${ }^{\mathrm{a}}$, Raphael de Campos Castilho ${ }^{\mathrm{b}}$, \\ Paulo Henrique Duarte Cançado ${ }^{c}$, Gilberto José de Moraes ${ }^{\mathrm{a}}$ \\ ${ }^{a}$ Department of Entomology and Acarology, Escola Superior de Agricultura Luiz de Queiroz (ESALQ), Universidade de São Paulo (USP), 13418-900 Piracicaba, SP, Brazil \\ ${ }^{\mathrm{b}}$ Department of Crop Protection, Faculdade de Ciências Agrárias e Veterinárias (FCAV), Universidade Estadual Paulista (UNESP), 14884-900 Jaboticabal, SP, Brazil \\ ${ }^{\mathrm{c}}$ Veterinarian Entomology Laboratory, Embrapa Gado de Corte, 79106-550 Campo Grande, MS, Brazil
}

\section{A R T I C L E I N F O}

\section{Keywords:}

Biological control

Predator

Life cycle

Stable fly

House fly

\begin{abstract}
A B S T R A C T
The stable fly (Stomoxys calcitrans) and horn fly (Haematobia irritans) are mainly parasites of cattle that spend the early phase of their life cycle in decaying vegetation, manure and soil, as members of a wide range of other harmful and beneficial arthropods. Predators of the family Macrochelidae are considered beneficial mites that have been considered promising biological control agents of fly eggs and larvae and of other harmful organisms. The objectives of this study were: a) to compare the predation and oviposition rates of three Macrocheles species, M. embersoni, M. muscaedomesticae and M. robustulus, on six prey species: $S$. calcitrans, Musca domestica , $H$. irritans, Bradysia matogrossensis, Rhizoglyphus echinopus and the free living nematode Rhabditella axei; b) to evaluate the life cycle of the best performing predator (M. embersoni) on the most suitable prey species at $30 \pm 2{ }^{\circ} \mathrm{C}, 95 \pm 5 \% \mathrm{RH}$ and in the dark. The three macrochelid species consumed all evaluated prey species, but $M$. embersoni had higher predation and daily oviposition rates on larvae of $S$. calcitrans (23.8 larvae consumed and laid about 4.0 eggs, respectively) than other species. Total immature development of $M$. embersoni was completed in at most about 1.3 days on eggs of $S$. calcitrans and $M$. domestica and 1.5 days on $R$. axei. Macrocheles embersoni produced most eggs (0.28-0.34 female/female/day; $\left.r_{\mathrm{m}}: 0.28-0.34\right)$ on those same prey. The results of this study suggest that $M$. embersoni is a promising biological control agent of $S$. calcitrans and $M$. domestica.
\end{abstract}

\section{Introduction}

Several fly species are known to be harmful to human beings and other animals. One of these is the stable fly, Stomoxys calcitrans (L.) (Diptera: Muscidae), whose adults are considered serious parasites of different animals, especially cattle, as well as humans, in different countries, including Australia, Colombia, Congo, Costa Rica, Tanzania and the United States (Fosbrooke, 1963; Herrero et al., 1989; Mora et al., 1997; Cook et al., 1999; Broce et al., 2005; Elkan et al., 2009). In Brazil, its importance has increased tremendously in recent years, especially in the central and southeastern states, in parallel with the increased field applications of vinasse, a byproduct of the alcohol and sugar industries, in sugarcane crops. The mixture of vinasse with sugarcane fallen sugarcane leaves constitutes a substrate for the development of immature stable flies (Cançado et al., 2013; Dominghetti et al., 2015).

The house fly, Musca domestica L. (Diptera: Muscidae), is one of the most common nuisance insects that as adults can vector microorganisms harmful to humans and other animals, and whose immatures develop in a variety of substrates, most often in animal manure and the soil (Legner, 1995; Mariconi et al., 1999; Skovgård and Nachman, 2004; Malik et al., 2007). The horn fly, Haematobia irritans (L.) (Diptera: Muscidae), is also considered an important harmful organism in several countries in Europe, Americas, Asia and non-tropical Africa. Adults of this species are cattle parasites, while immatures develop in cattle droppings (Barros, 2001; Pruett et al., 2003; Almeida et al., 2010).

\footnotetext{
* Corresponding author.

E-mail addresses: leticiaazevedo@usp.br (L.H. Azevedo), murilo.ferreira@usp.br (M.P. Ferreira), raphael.castilho@unesp.br (R.d.C. Castilho), paulo.cancado@embrapa.br (P.H.D. Cançado), moraesg@usp.br (G.J. de Moraes).
} 
Several other soil organisms can cause severe damage to cultivated plants. Examples are the fungus gnats (Diptera: Sciaridae) and the bulb mite, Rhizoglyphus echinopus (Fumouze and Robin) (Astigmatina: Acaridae), which damage plant parts just below the soil surface (Gerson et al., 2003).

Control of those organisms is often made difficult for the secluded microhabitats they occupy, but chemicals are often used for their control. Thus, evaluation of the potential of natural enemies for the control of those organisms is warranted. The Macrochelidae constitute an abundant and diverse group of soil predatory mites, mostly associated with decomposing organic matter where fly larvae are commonly found (Gerson et al., 2003; Lindquist et al., 2009; Azevedo et al., 2015). This large group comprises about 520 species, some of which have been evaluated for some time for their predaceous behavior on fly larvae and immatures of other invertebrates (Krantz, 1983; Azevedo et al., 2015).

One of these species, Macrocheles robustulus (Berlese), has been commercialized in Europe for the control of fungus gnats, thrips (Thysanoptera) and a species of Lyprauta fly (Diptera: Keroplatidae). However, nothing is known about the biology and potential as control agents of the vast majority of macrochelid species. Information about some species of this group indicates that some of the insufficiently known species may be useful as biological control agents of organisms which spend all or part of their lives in the soil.

The objectives of this study were: a) to compare the predation and oviposition rates of Macrocheles embersoni Azevedo, Berto and Castilho (Azevedo et al., 2017), Macrocheles muscaedomesticae (Scopoli) and M. robustulus on six prey species: $S$. calcitrans, $M$. domestica, $H$. irritans, the fungus gnat Bradysia matogrossensis (Lane) (Diptera: Sciaridae), the bulb mite $R$. echinopus and the free livingnematode Rhabditella axei (Cobbold) (Nematoda: Rhabditidae); b) to evaluate the life cycle of the most promising predator species when fed with the prey it best performed on the preceding evaluation.

\section{Materials and methods}

The study was conducted between October 2014 and November 2015. Voucher specimens of the macrochelid species studied were deposited in the mite reference collection of "Departamento de Entomologia e Acarologia, Escola Superior de Agricultura Luiz de Queiroz, Universidade de São Paulo", Piracicaba, State of São Paulo, Brazil. The study was conducted in incubators, at $30 \pm 2{ }^{\circ} \mathrm{C}$, $95 \% \pm 5 \%$ RH and in the dark. Each experimental unit consisted of a transparent plastic Petri dish $(2.7 \mathrm{~cm}$ in diameter $\mathrm{x} 1.2 \mathrm{~cm}$ in height) whose bottom was covered with a layer of $0.5 \mathrm{~cm}$ of a mixture of gypsum and activated charcoal (9:1; Abbatiello, 1965). This layer was maintained wet by daily addition of distilled water. The open end of the unit was sealed with a piece of transparent plastic film (Magipac ${ }^{\circledast}$ ), to prevent mites from escaping.

\subsection{Stock colony}

Specimens of M. embersoni, M. muscaedomesticae and M. robustulus were collected from cattle droppings respectively at Araçoiaba da Serra, Piracicaba and Cabralia Paulista, all in São Paulo State, Brazil, in February 2014. The colonies were maintained in the laboratory in plastic units ( $8 \mathrm{~cm}$ diameter and $7 \mathrm{~cm}$ high), whose bottom was covered with a layer of the mixture of gypsum and activated charcoal reported in the previous paragraph, which was also maintained wet by daily addition of distilled water. Each unit was filled to $70 \%$ of its capacity with vermiculite. The predatory mites were fed with a mixture of all stages of $R$. axei and with eggs and larvae of the house fly.

Colonies of $R$. axei were maintained in plastic containers with rotting pieces of pods of Canavalia ensiformis L. soaked in distilled water. Larvae of house flies were maintained in moist wheat bran in a plastic cage, whereas adults were maintained in a similar, separate cage and fed a mixture of milk $(100 \mathrm{ml})$ with sugar $(1 \mathrm{~g})$. Bradysia matogrossensis and $R$. echinopus were also maintained in the laboratory in cages containing respectively a moistened commercial dog food (Deli Dog Purina $^{\circledR}$ ) inoculated with the fungus Rhizopus sp. or just the same moistened dog food. Eggs and larvae of $S$. calcitrans (stable fly) were obtained from a rearing maintained at the veterinarian entomology laboratory of "Embrapa Beef Cattle", Campo Grande, Mato Grosso do Sul State, where larvae were fed a mixture of vegetables and proteins adapted from Christmas (1970) and adults were fed cattle blood. Eggs of $H$. irritans (horn fly) were obtained from field collected adults. Due to this fact, the number of available eggs of this last fly was limited, and thus it could be tried as prey for only two of the predator species ( $M$. muscaedomesticae and M. embersoni).

\subsection{Predation and oviposition}

The method adopted was based on similar previous studies of predatory mites of the families Phytoseiidae, Rhodacaridae and Laelapidae (Furtado et al., 2007; Castilho et al., 2009; Moreira et al., 2015).

Initially, the following prey species were separately transferred to each experimental unit: 50 eggs of $S$. calcitrans, 50 first instar larvae (L1) of $S$. calcitrans, 20 eggs of $M$. domestica, 20 first instar larvae (L1) of $M$. domestica, 20 eggs of $H$. irritans, 20 first instar larvae (L1) of B. matogrossensis, 30 nymphs of $R$. echinopus, or a surplus amount of $R$. axei (determined in preliminary tests). In the latter case, the nematodes were maintained in each unit on a small piece of jack bean pod. Soon after, a 0-2 day old gravid adult female of a predatory mite was transferred from the stock colony to a unit. Each unit constituted a replicate and 30 replicates were considered for each species of predatory mite.

The units were examined at $12 \mathrm{~h}$ intervals for 11 consecutive days to determine the number of prey killed and the number of eggs laid by the predator and its survivorship. The number of nematodes killed was not determined, because of the difficulty in doing so with the adopted methodology. At each examination, prey killed were replaced and eggs laid were discarded. Eggs laid on the first day were excluded from analysis because of the possible influence of previous feeding.

Predation and oviposition rates were compared statistically between predators on each prey species. For each predator average predation rates on different prey were not compared statistically, because of their different biomasses, but average oviposition rates were. Comparison was done by ANOVA, in a completely randomized design, followed comparisons of means by Tukeýs test $(5 \%)$, after $(\sqrt{ } \mathrm{x}+0.5)$ transformation.

\subsection{Biological parameters of the most promising predator}

Based on the results obtained in the previous study, the biology of the most promising predator was evaluated on the most suitable prey species.

A life table study was initiated with fifty $0-3 \mathrm{~h}$ old predator eggs, each in an experimental unit. After eclosion, each predator was fed ad libitum with one of the selected prey. The units were examined every $3 \mathrm{~h}$ to determine the duration of each immature stage. After reaching adulthood, females were paired with males taken randomly from the colony. Twenty four hours later, the males were removed, to prevent cannibalism. The units were examined daily at $7 \mathrm{AM}$ and $7 \mathrm{PM}$, to determine the duration of each adult phase as well as oviposition, discarding the eggs.

To determine the survivorship and possible oviposition of the predator in the absence of prey, 25 female deutonymphs (distinctly large, posteriorly rounded and yellowish, in comparison with the smaller, posteriorly tapered and whitish male deutonymphs) were each isolated in an experimental unit similar to those previously described. The experimental units were maintained without prey but moistened by daily addition of distilled water to the absorbing base of the units. After mites reached adulthood, the units were examined every $24 \mathrm{~h}$, to determine survivorship. 
Table 1

Number of prey killed daily by three macrochelid species at $30 \pm 2{ }^{\circ} \mathrm{C}$, $95 \% \pm 5 \% \mathrm{RH}$ and in the dark.

\begin{tabular}{llll}
\hline Prey & Predators & & \\
\cline { 2 - 4 } & $\begin{array}{l}\text { Macrocheles } \\
\text { embersoni }\end{array}$ & $\begin{array}{l}\text { Macrocheles } \\
\text { muscaedomesticae }\end{array}$ & $\begin{array}{l}\text { Macrocheles } \\
\text { robustulus }\end{array}$ \\
\hline Stomoxys calcitrans (eggs) & $12.5 \pm 0.6 \mathrm{a}$ & $8.7 \pm 0.9 \mathrm{~b}$ & $3.5 \pm 0.5 \mathrm{c}$ \\
S. calcitrans (L1) & $23.8 \pm 1.0 \mathrm{a}$ & $7.2 \pm 1.0 \mathrm{c}$ & $15.1 \pm 1.0 \mathrm{~b}$ \\
Musca domestica (eggs) & $12.4 \pm 0.7 \mathrm{a}$ & $11.0 \pm 1.2 \mathrm{a}$ & $4.4 \pm 0.6 \mathrm{~b}$ \\
M. domestica (L1) & $8.9 \pm 1.7 \mathrm{a}$ & $2.5 \pm 0.1 \mathrm{~b}$ & $3.5 \pm 0.5 \mathrm{~b}$ \\
Haematobia irritans (eggs) & $5.5 \pm 0.4 \mathrm{a}$ & $4.3 \pm 0.4 \mathrm{a}$ & $\begin{array}{l}\text { Not evaluated } \\
\text { Bradysia matogrossensis }\end{array}$ \\
$\begin{array}{l}6.4 \pm 0.2 \mathrm{a} \\
\text { Rhizoglyphus echinopus }\end{array}$ & $0.9 \pm 0.4 \pm 0.2 \mathrm{~b}$ & $<0.1 \mathrm{~b}$ & $4.1 \pm 0.5 \mathrm{a}$ \\
\hline
\end{tabular}

Means followed by the same letters in each line are not significantly different (Tukeýs test, $p>0.05$ ).

\subsection{Statistical analysis}

The mean duration of each stage, as well as of the total immature phase (egg-adult), and duration of the periods of pre-oviposition, oviposition, post-oviposition, longevity and fecundity on each prey were submitted to analyses of variance, using non parametric Kruskal-Wallis test for comparisons of treatments. Net reproductive rate $\left(R_{o}\right)$, intrinsic rate of population increase $\left(r_{m}\right)$, finite rate of population increase $(k)$, mean generation time (T) and the standard errors were calculated using "Bootstrap" procedure and compared by Student's $t$ test using "LifeTable.SAS" in the software "SAS System" (Maia et al. 2000; Maia and Luiz, 2006).

\section{Results}

\subsection{Predation and oviposition}

The three macrochelid species consumed all evaluated prey types, but there were some major differences between predators (Table 1). Predation rates were generally highest for $M$. embersoni, except on eggs of $M$. domestica and $H$. irritans (statistically the same as of M. muscaedomesticae), on B. matogrossensis (same as of $M$. robustulus), and on $R$. echinopus (lower than of $M$. robustulus) $(\mathrm{F}=58.34$, $\mathrm{df}=2, p \leq 0.0001)$.

The three macrochelid species also oviposited on all prey types, although major differences were also observed between means (Table 2). Daily oviposition rates were generally highest for M. embersoni ( $\mathrm{F} \geq 21.42$, $\mathrm{df}=2, p \leq 0.0001$ ), although on $B$. matogrossensis and $R$. echinopus oviposition rates by this predator were statistically the same as those by $M$. robustulus. The highest oviposition rate of $M$. embersoni (5.4 eggs/female) was observed on $R$. axei $(\mathrm{F}=36.92$, $\mathrm{df}=2 p<0.0001$ ), although oviposition was also relatively high
(1.5-4.3 eggs/female) on other prey, except on $R$. echinopus. The highest oviposition rate of M. muscadomesticae was observed on $R$. axei and on eggs and larvae of $M$. domestica (1.1-1.7 eggs/female; $\mathrm{F}=53.52, \mathrm{df}=2, p<0.0001)$, while on other prey oviposition was low ( $\leq 0.8 \mathrm{eggs} / \mathrm{female}$ ). Conversely, the highest oviposition rate of $M$. robustulus was observed on larvae of $B$. matogrossensis and $S$. calcitrans (2.3 eggs/female; $\mathrm{F}=61.57, \mathrm{df}=2, p<0.0001$ ); on $R$. axei and on $M$. domestica eggs and larvae oviposition was 1.9-2.0 eggs/female.

Feeding on $R$. echinopus resulted in extremely low oviposition rates by the three predators, while feeding on $B$. matogrossensis also resulted in extremely low oviposition of M. muscaedomesticae. Survivorship of all predators was high $(\geq 73 \%)$ on all prey items.

\subsection{Biological parameters}

From the results of the previous test, the predator selected for this study was $M$. embersoni and the prey were $R$. axei, $S$. calcitrans and $M$. domestica, the first a mixture of all developmental stages and others in the egg stage (Table 3) (Fig. 1a-c). For each immature stage and for the combined immature phase (egg-adult), differences in durations were small, although durations were significantly longer on $R$. axei for the deutonymphal stage and for the entire immature phase $\left(\chi^{2}>76.874\right.$, $\mathrm{df}=2, p<0.0001$ ). Survivorship of each stage was high on all prey species (77-97\%) while survivorship for the entire immature phase (egg-adult) ranged between 61.5 and $63.9 \%$.

The oviposition period was longer $\left(\chi^{2}>95.738, \mathrm{df}=2\right.$, $p<0.0001$ ) whereas pre-oviposition and post-oviposition and female longevity were shorter $\left(\chi^{2 \mathrm{v}} \geq 61.492, \mathrm{df}=2, p<0.0001\right)$ on $R$. axei. For each of those parameters, no significant differences were observed for predator fed $S$. calcitrans and M. domestica. After adult emergence, the proportions of females were about the same on R. axei and M. domestica, but significantly lower on $S$. calcitrans. Male longevity was shorter on $S$. calcitrans than $M$. domestica and R. axei, but no significant differences were observed between the latter two treatments.

For all prey species, daily oviposition reached the highest rates 7-15 days of the beginning of the oviposition period, with maximum rates varying from 4.5 eggs/female on $M$. domestica to 7.4 on $R$. axei (Fig. 2). Oviposition reduced slowly afterward, reaching very low levels at the end of 21-30 days. Fecundity was significantly higher on $R$. axei $(77.2 \pm 5.1)$, than on $S$. calcitrans $(58.0 \pm 5.9)$ and on $M$. domestica $(55.0 \pm 5.3)\left(\chi^{2}>37.574, \mathrm{df}=2, p<0.0001\right)$. About $80 \%$ of all eggs were laid in the first 13-15 days of oviposition on the three prey. Female survivorship reached $50 \%$ respectively after 21,40 and 36 days after emergence on $R$. axei, $S$. calcitrans and $M$. domestica, all females dying after 35,45 and 48 days, respectively.

The population of $M$. embersoni increased approximately 34 times at each generation on $R$. axei $\left(\mathrm{R}_{\mathrm{o}}=34.12\right)$, rate significantly higher than on other prey (Table 4 ). Yet, the predator produced about 0.34 female/

Table 2

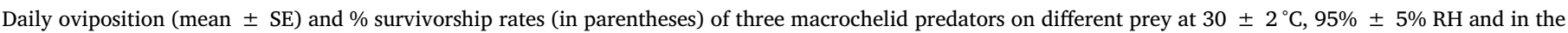
dark.

\begin{tabular}{|c|c|c|c|}
\hline \multirow[t]{2}{*}{ Prey } & \multicolumn{3}{|l|}{ Predators } \\
\hline & Macrocheles embersoni & Macrocheles muscaedomesticae & Macrocheles robustulus \\
\hline S. calcitrans (eggs) & $4.3 \pm 0.4 * \mathrm{Ba}\left(\begin{array}{lll}1 & 0 & 0\end{array}\right)$ & $0.8 \pm 0.2 \mathrm{Bb}(98.0)$ & $0.6 \pm 0.1 \mathrm{Cb}(90.0)$ \\
\hline S. calcitrans (L1) & $4.2 \pm 0.5 \mathrm{Ba}(99.0)$ & $0.5 \pm 0.1 \mathrm{Cc}(85.0)$ & $2.3 \pm 0.3 \mathrm{Ab}(98.0)$ \\
\hline M. domestica (eggs) & $3.1 \pm 0.4 \mathrm{Ca}(93.0)$ & $1.5 \pm 0.2 \mathrm{Ab}(87.0)$ & $1.9 \pm 0.2 \mathrm{Bb}(87.0)$ \\
\hline M. domestica (L1) & $3.6 \pm 1.1 \mathrm{Ca}(95.0)$ & $1.1 \pm 0.1 \mathrm{ABb}(90.0)$ & $1.9 \pm 0.9 \mathrm{Bb}(85.0)$ \\
\hline H. irritans (eggs) & $1.5 \pm 0.3 \mathrm{Da}(98.0)$ & $0.4 \pm 0.1 \mathrm{Cb}(98.0)$ & Not evaluated \\
\hline B. matogrossensis & $2.7 \pm 0.5 \mathrm{Ca}(91.0)$ & $<0.1 \mathrm{Db}(80.0)$ & $2.3 \pm 0.6$ Аа $(73.0)$ \\
\hline R. echinopus & $0.2 \pm 0.04 \mathrm{Ea}(83.0)$ & $<0.1 \mathrm{Db}(90.0)$ & $0.1 \pm 0.04 \mathrm{Da}(83.0)$ \\
\hline R. axei & $5.4 \pm 1.5 \mathrm{Aa}(85.0)$ & $1.7 \pm 0.6 \mathrm{Ab}(84.0)$ & $2.0 \pm 1.0 \mathrm{Bb}(78.0)$ \\
\hline
\end{tabular}

* Means followed by the same uppercase letters in each column and lowercase letters in each line are not significantly different (Tukey's test, $p>0.05$ ). 
Table 3

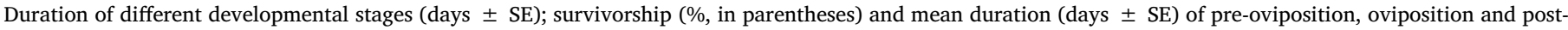

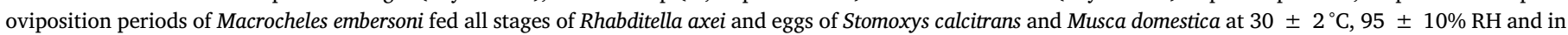
the dark.

\begin{tabular}{|c|c|c|c|}
\hline \multirow[t]{2}{*}{ Stages } & \multicolumn{3}{|l|}{ Prey } \\
\hline & R. axei & S. calcitrans & M. domestica \\
\hline Egg & $0.3 \pm 0.04 a(86.0)$ & $0.3 \pm 0.02 \mathrm{a}(96.0)$ & $0.3 \pm 0.02 \mathrm{a}(96.0)$ \\
\hline Larva & $0.2 \pm 0.02 \mathrm{a}(91.0)$ & $0.2 \pm 0.01 \mathrm{a}(94.2)$ & $0.2 \pm 0.01 \mathrm{a}(98.0)$ \\
\hline Protonymph & $0.3 \pm 0.03 a(95.0)$ & $0.4 \pm 0.03 a(92.0)$ & $0.4 \pm 0.03 a\left(\begin{array}{lll}1 & 0 & 0\end{array}\right)$ \\
\hline Deutonymph & $0.7 \pm 0.06 b(97.3)$ & $0.4 \pm 0.03 a(93.3)$ & $0.4 \pm 0.02 \mathrm{a}\left(\begin{array}{lll}1 & 0 & 0\end{array}\right)$ \\
\hline Egg-adult & $1.5 \pm 0.03 b(72.0)$ & $1.3 \pm 0.01 \mathrm{a}(78.0)$ & $1.3 \pm 0.01 \mathrm{a}(94.0)$ \\
\hline Pre-oviposition & $1.3 \pm 0.08 \mathrm{a}$ & $2.9 \pm 1.1 b$ & $2.9 \pm 0.18 b$ \\
\hline Oviposition & $19.5 \pm 1.1 b$ & $14.1 \pm 1.1 \mathrm{a}$ & $16.2 \pm 0.59 \mathrm{a}$ \\
\hline Post-oviposition & $2.9 \pm 0.6 \mathrm{a}$ & $17.6 \pm 1.8 \mathrm{~b}$ & $14.9 \pm 1.60 \mathrm{~b}$ \\
\hline Female longevity & $23.5 \pm 1.4 \mathrm{a}$ & $30.1 \pm 2.1 b$ & $29.3 \pm 2.10 \mathrm{~b}$ \\
\hline Male longevity & $13.6 \pm 1.3 \mathrm{~b}$ & $8.8 \pm 0.9 a$ & $17.4 \pm 0.71 b$ \\
\hline Sex ratio $\left(q, \sigma^{\prime}\right)$ & $25,7(=78 \%)$ & $27,17(=61 \%)$ & $35,12(=74 \%)$ \\
\hline
\end{tabular}

Means followed by the same letters in each line are not significantly different (Tukey's test, $p>0.05$ ).

female/day $\left(r_{m}=0.34\right)$ on $S$. calcitrans, value significantly higher than on other prey. Concurrently, daily increase in population size was about $41 \%(\lambda=1.41)$ on $S$. calcitrans, a value also significantly higher than on other prey. Also, mean duration of a generation of the predator was significantly longer on $R$. axei $(\mathrm{T}=12.5$ days) than on other prey.

\subsection{Survivorship and oviposition in the absence of food}

All deutonymphs survived and developed to the adult stage. Adults survived for a relatively long period without food (20.5 \pm 6.1 days). Regardless of starvation, 16 out of the 25 evaluated females (64\%)
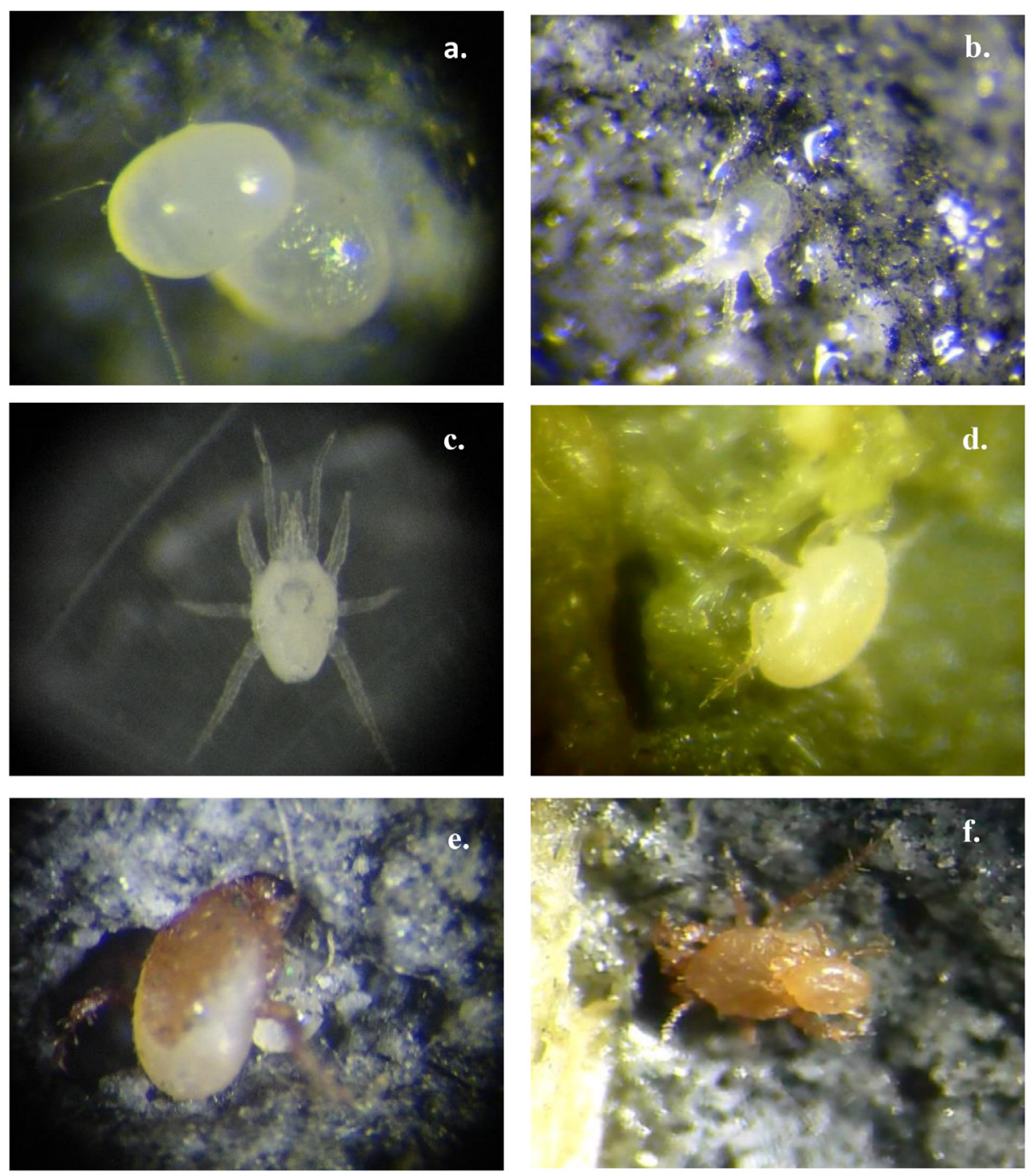

Fig. 1. Macrocheles embersoni. a - eggs; b - larvae; c - protonymphal stage; $\mathrm{d}$ - deutonymphal stage; e - adult female hiding the eggs; $\mathrm{f}$ - copulation. 

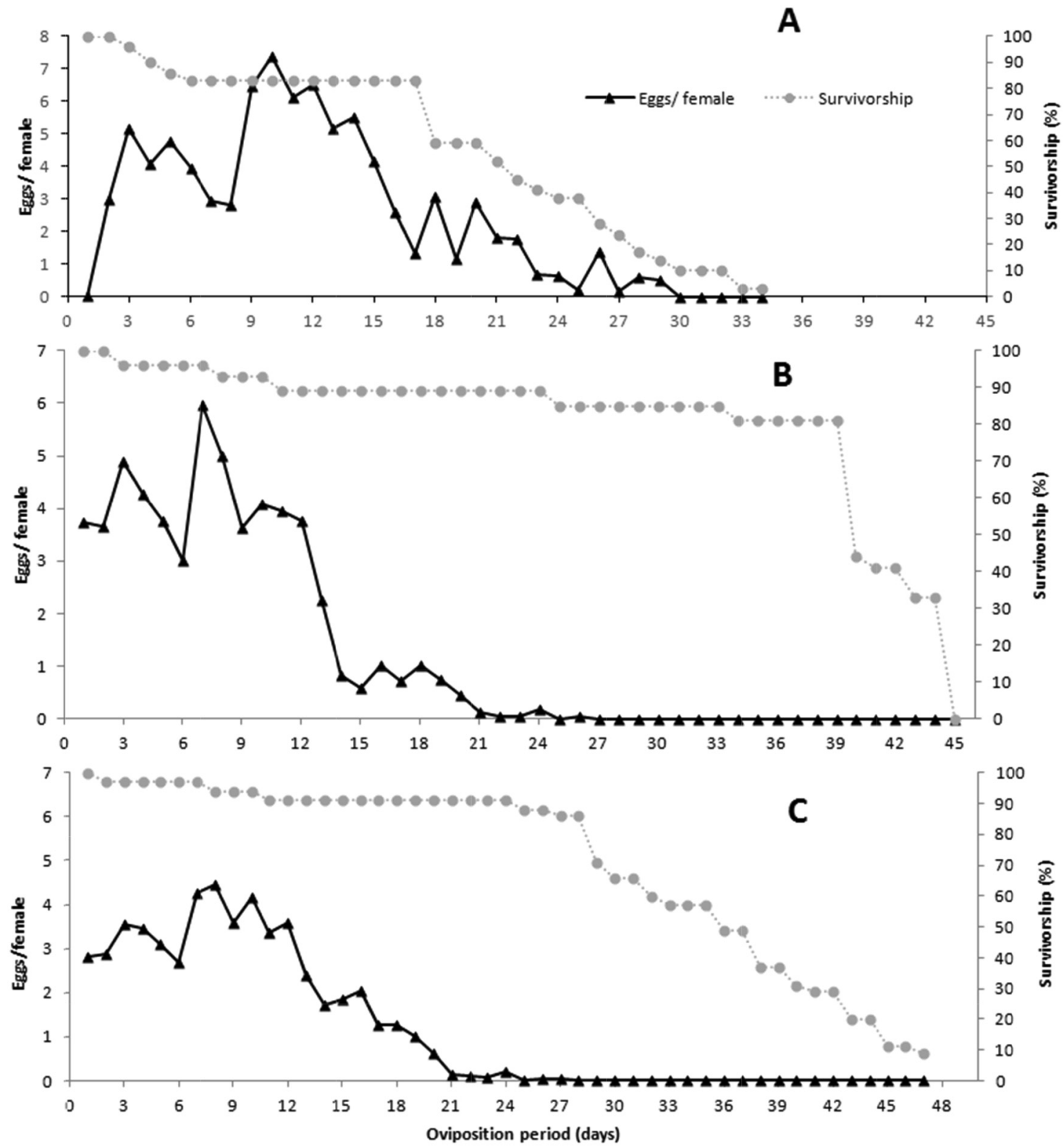

Fig. 2. Mean daily oviposition (eggs/female/day) of Macrocheles embersoni fed all stages of Rhabditella axei (A), and eggs of Stomoxys calcitrans (B) and Musca domestica (C) at $30 \pm 2{ }^{\circ} \mathrm{C}, 95 \pm 10 \% \mathrm{RH}$ and in the dark.

Table 4

Life table parameters of Macrocheles embersoni fed all stages of Rhabditella axei and eggs of Stomoxys calcitrans and Musca domestica at $30 \pm 2{ }^{\circ} \mathrm{C}, 70 \pm 10 \%$ $\mathrm{RH}$ and in the dark. $\mathrm{R}_{\mathrm{o}}$ : net reproductive rate, $\mathrm{r}_{\mathrm{m}}$ : intrinsic rate of increase, $\lambda$ : finite rate of increase, T: mean generation time in days.

\begin{tabular}{llllll}
\hline Prey & $\mathrm{n}$ & $\mathrm{R}_{\mathrm{o}}$ & $\mathrm{r}_{\mathrm{m}}$ & $\lambda$ & $\mathrm{T}$ \\
\hline R. axei & 25 & 34.12 & 0.28 & 1.32 & 12.5 \\
S. calcitrans & 27 & 30.80 & 0.34 & 1.41 & 9.9 \\
M. domestica & 35 & 30.59 & 0.31 & 1.37 & 10.9 \\
\hline
\end{tabular}

oviposited, resulting in an overall oviposition of $0.6 \pm 0.14 \mathrm{eggs} / \mathrm{fe}-$ male; one female laid two eggs while others laid a single egg, always on the first day after emergence, except for one female, which oviposited a single egg on the third day.

\section{Discussion}

Considerable differences were found between the evaluated predator species concerning the ability to feed and oviposit on different prey. The results were very promising, especially in relation to $M$. embersoni on almost all prey items (except on $R$. echinopus). This predator not only performed better than other predators evaluated in this work, but also in comparison with what has been reported in the literature for other predators of the same or other families on the same or related prey.

However, predation and oviposition rates of the evaluated predators on $R$. echinopus were very low when compared to predators of other families (Ragusa and Zedan, 1988; Castilho et al., 2015; Moreira and Moraes, 2015; Massaro et al., 2016). Soliman et al. (1978) also reported the inability of Macrocheles matrius Hull to feed on R. echinopus.

The predation rates on eggs of $H$. irritans by $M$. embersoni and $M$. muscaedomesticae were higher (at least 30\%) than reported by Halliday and Holm (1987) and Perotti (2001) for M. robustulus and by Doube 
et al. (1986) for Macrocheles peregrinus Krantz. Not much effort has been dedicated to the evaluation of mites as predators of this fly (Azevedo et al., 2015). Perotti (2001) mentioned that the biggest mites were able to attack eggs with a heavy chorion while the smaller mites caused mortality mainly among eggs with light chorion.

Literature about the potential of macrochelids as control agents of M. domestica is very extensive (Azevedo et al., 2015). Oviposition and prey consumption rates of the Brazilian M. embersoni, M. muscaedomesticae and $M$. robustulus on eggs and larvae of that fly were higher than those determined for $M$. muscaedomesticae and $M$. robustulus from other countries (Wade and Rodriguez, 1961; Singh et al., 1966; Afifi, 1989; Ho, 1989; Guanilo and Cordero, 2003).

Predation and oviposition rates by $M$. embersoni and $M$. robustulus on B. matogrossensis were higher (at least $45 \%$ ) than reported by Castilho et al. (2009) for Protogamasellopsis zaheri Abo-Shnaf, Castilho and Moraes (reported as Protogamasellopsis posnaniensis Wisniewski and Hirschmann) (Rhodacaridae) on the same prey, and by Wright and Chambers (1994) for Stratiolaelaps miles (Berlese) (cited as Hypoaspis miles) (Laelapidae) on Bradysia paupera Tuomikoski. Predation and oviposition rates of $M$. muscaedomesticae on B. matogrossensis were very low in relation to the other predators evaluated in this work. These low rates could be due to the unsuitability of that species as prey, but alternatively to the aggressive behavior of the prey. Castilho et al. (2009) demonstrated the ability of larvae of $B$. matogrossensis to prey on eggs of the predatory mite $P$. zaheri. Aggressive behavior by larvae of $M$. domestica has also been observed in our laboratory, even towards adult predators. In that unpublished work, several prey larvae were observed to move towards a predator attacking a nearby member of their population, driving the predator away. Aggressive behavior of dipteran species towards macrochelids deserves further evaluation.

The high rate of oviposition by M. embersoni on $R$. axei is compatible with the easiness with which the colony of this predatory mite is maintained in the laboratory using that nematode species, together with eggs and larvae of $M$. domestica larvae as prey. Ito (1973) also observed that reproduction of $M$. muscaedomesticae was remarkably enhanced when nematodes were offered as prey. Several studies have demonstrated the preference of macrochelid immatures for nematodes and of macrochelid adults for fly immatures as prey (Filipponi and Delupis, 1963).

Confirming the results of the predation tests, M. embersoni was able to complete its life cycle on all stages of $R$. axei and on eggs of $S$. calcitrans and $M$. domestica in the life table study. The similar duration of the egg and larval stages in the presence of different prey was expected, given that eggs do not feed and that larvae were never observed feeding in this study. Costa $(1966 ; 1967)$ also observed that larvae of respectively $M$. robustulus and Macrocheles parapisentii Costa did not feed. Nonfeeding larvae seem common in Macrocheles species.

Macrocheles embersoni laid its eggs in protected places in the rearing unit, in irregularities of the base of the unit; in some cases, females were observed pushing particles onto the eggs, as if hiding them. In several occasions, larval development (especially the presence of distinct appendages) was observed in eggs inside slide mounted gravid females, but larval emergence from eggs always required a few hours to occur; ovoviviparity (emergence of larvae from the eggs soon after oviposition) was never observed. Marquardt et al. (2015) reported ovoviviparity to be facultative in several Macrocheles species and related to the occurrence of unfavorable environmental conditions.

The quick immature development of $M$. embersoni on all prey is similar to that reported by Filipponi and Mosna (1968) for M. robustulus and by Cicolani et al. (1977) for Macrocheles subbadius (Berlese), on $M$. domestica. Duration of the immature phase is much shorter than reported for other common groups of predatory mesostigmatids in the literature (see for example McMurtry et al., 2015 for phytoseiids and Moreira and Moraes, 2015 for laelapids).

Immatures were rarely observed moving onto the rearing unit, most often remaining quite in secluded places. Male guarding quiescent deutonymphs were often observed, with mating of very short duration occurring while females were still molting to the adult stage.

Cannibalism of immature by adults was occasionally observed. While cannibalism could reflect unsuitability of available prey in a rearing process, making predators more prone to prey on more vulnerable stages of their own, it can also represent an important survivorship strategy for species that usually occupy temporarily suitable habitats, together with quick development and secluded behavior (Tayeh et al., 2014). Marquardt et al. (2015) added to those two other characteristics, ovoviviparity and phoresis, the latter not evaluated in this study. Ability to survive long periods of starvation, to oviposit (albeit few eggs) before feeding and to copulated quickly after female reaches adulthood should also be added as important for that strategy.

The results of the present study showed adequate biological performance of $M$. embersoni on $S$. calcitrans. The values of intrinsic rate of population increase were comparable to what has been reported for Phytoseiulus persimilis Athias-Henriot and Phytoseiulus macropilis (Banks), mites of the family Phytoseiidae widely used commercially for the control of pest mites of the family Tetranychidae (Sabelis, 1985), as well as for Phytoseiulus longipes Evans (Furtado et al., 2007). Values of intrinsic rate of population increase reported for Phytoseiulus species are considered high within the Phytoseiidae. Rates were also higher than reported by Enkegaard et al. (1997) for S. miles (cited as Hypoaspis miles) on Sciaridae species $\left(r_{m}=0.074\right)$. This laelapid species has also been used commercially for the control of various harmful soil organisms (Moreira and Moraes, 2015).

In what seems to be the only other study about potential of predatory mites to control $S$. calcitrans, Kinn (1966) reported that $M$. muscaedomesticae would be ineffective as its control agent, because of the low predation rate, which the author assumed to be possibly because of the thick chorion in comparison with that of $M$. domestica. The rate in that study (maximum $4.3 \mathrm{eggs} / \mathrm{female} /$ day) was much lower than observed for the Brazilian population of the same predator, and still much lower than observed for M. embersoni. Given the great importance of $S$. calcitrans in Brazil and elsewhere, complementary studies about the possible use of $M$. embersoni for its control are warranted.

The result of this study seems relevant, given the major difficulty presently faced in controlling $S$. calcitrans in Brazil with any type of strategy. The problem caused by this fly in parts of central and southeastern Brazil nowadays is considered of major concern to both cattle raisers and sugarcane producers (Koller et al., 2009). The discovery of promising species for the control of this parasite is highly desirable.

Results obtained with $M$. domestica were similar to those obtained on S. calcitrans. Although Cicolani (1979) reported a much higher intrinsic rate of population increase (0.90) for $M$. muscaedomesticae on $M$. domestica, the oviposition period of M. embersoni was about 1.2 times longer, fertility was about twice higher, and intrinsic rate of increase was about 1.3 times higher than determined by Almeida (1994) for $M$. muscaedomesticae on the same prey. Thus, the results of this work suggest that $M$. domestica is a suitable prey for the mass production of $M$. embersoni. In a mass production program, the use of $M$. domestica as prey may be more convenient than the use of other food sources, given the easiness with which this prey can be produced. However, the biological performance of $M$. embersoni on $R$. axei indicate that free-living nematodes could also be important as factitious food, for maintaining these predators under natural conditions or, potentially, to maintain field released M. embersoni in a biological control program. Rodrigues et al. (1962) also reported M. muscaedomesticae to reproduce relatively fast when fed with the nematode Rhabditella leptura (Cobb) (Rhabditidae).

In conclusion, the results of this study suggested that M. embersoni is a promising biological control agent of $S$. calcitrans and $M$. domestica, and that it could be mass reared with the use of $R$. axei or/and eggs of $M$. domestica. Future studies of this predator should involve an evaluation of its development and reproduction when nematodes and fly immatures are offered together as prey. Also important is to study the 
dispersal process of $M$. embersoni under natural conditions, given the importance of phoresy for this mite group. Knowledge about this aspect is essential for the potential use of the predator in the control of $S$. calcitrans and possibly other pests or parasites.

\section{Acknowledgments}

The authors are thankful to D.M. Rueda-Ramírez and G.S.P. Barroso for help conducting the biological parameters tests. To Dr. Antônio Thadeu M. de Barros, Dr. Carlos H.W. Flechtmann and Dr. Eric Palevsky for his help during the preparation of this manuscript with valuable suggestions. To $\mathrm{CNPq}$ (Conselho Nacional de Desenvolvimento Científico e Tecnológico, Brazil) for the fellowship provided to the second author and for finance part of the research. To FUNDECT and EMBRAPA for collaborating with the project. Part of this work was supported by the "Fundação de Amparo a Pesquisa do Estado de São Paulo" (FAPESP) within the Pós-Doutorado program (Proc. no. 2016/ 19747-7).

\section{References}

Afifi, A.M., 1989. Laboratory studies on the biology and feeding habitats of three macrochelid mites (Acari: Gamasida: Macrochelidae). Bull. Entomol. Soc. Egypt 68, 169-174.

Almeida, N.W., 1994. Caracterizaç̃o de alguns parâmetros biológicos de Macrocheles muscaedomesticae (Scopoli, 1772) (Acari: Gamasida) associada às moscas sinantrópicas em granja de aves poedeiras de Monte-Mor, S.P. (Acarina: Mesostigmata: Macrochelidae). Universidade Estadual de Campinas, Campinas.

Almeida, F.A., Basso, F.C., Seno, M.C.Z., Filho, W.V.V., 2010. Dinâmica populacional da mosca-dos-chifres (Haematobia irritans) em bovinos da raça Guzerá e mestiço em Selvíria,. MS Ciênc. Agrár. 31, 157-162.

Azevedo, L.H., Emberson, R.M., Esteca, F.C.N., Moraes, G.J., 2015. Macrochelid mites (Mesostigmata: Macrochelidae) as biological control agents. In: Carrilo, D., Moraes, G.J., Peña, J. (Eds.), Prospects for Biological Control of Plant Feeding Mites and Other Harmful Organisms. Springer International Publishing, Switzerland, pp. 103-132.

Azevedo, L.H., Castilho, R.C., Berto, M.M., Moraes, G.J., 2017. Macrochelid mites (Mesostigmata: Macrochelidae) from São Paulo state, Brazil, with description of a new species of Macrocheles. Zootaxa 4269 (3), 413-426.

Barros, A.T.M., 2001. Dynamics of Haematobia irritans irritans (Diptera: Muscidae) infestation on Nelore cattle in the Pantanal, Brazil. Mem. Inst. Oswaldo Cruz 96, $445-450$.

Broce, A.B., Hogsette, J., Paisley, S., 2005. Winter feeding sites of hay in round bales as major developmental sites of Stomoxys calcitrans (Diptera: Muscidae) in pastures in spring and summer. J. Econ. Entomol. 98, 2307-2312.

Cançado, P.H.D., Barros, A.T.M., Catto, J.B., Koller, W.W., Soares, C.O., 2013. Uso da queima profilática no controle emergencial e prevenção de surtos pela mosca-dosestábulos (Stomoxys calcitrans) em propriedades produtoras de cana-de-açúcar. Embrapa (Comunicado técnico), vol. 126, 1-4.

Castilho, R.C., de Moraes, G.J., Silva, E.S., Freire, R.A.P., da Eira, F.C., 2009. The predatory mite Stratiolaelaps scimitus as a control agent of the fungus gnat Bradysia matogrossensis in commercial production of the mushroom Agaricus bisporus. Int. J. Pest Manage. 55 (3), 181-185.

Castilho, R.C., Venancio, R., Narita, J.P. Z, 2015. Mesostigmata as biological control agents, with emphasis on Rhodacaroidea and Parasitoidea. In: Carrilo, D., Moraes, G.J., Peña, J. (Eds.), Prospects for Biological Control of Plant Feeding Mites and Other Harmful Organisms. Springer International Publishing, Switzerland, pp. 1-31.

Cicolani, B., 1979. The intrinsic rate of natural increase in dung macrochelid mites, predators of Musca domestica eggs. Boll. Zool. 46 (3), 171-178.

Cicolani, B., Passariello, S., Petrelli, G., 1977. Influenza della temperatura su I'incremento di popolazione in Macrocheles subbadius (Acarina: Mesostigmata). Acarologia 19, 563-578.

Cook, D.F., Dadour, I.R., Keals, N.J., 1999. Stable fly, house fly (Diptera: Muscidae), and other nuisance fly development in poultry litter associated with horticultural crop production. J. Econ. Entomol. 92, 1352-1357.

Costa, M., 1966. Notes on macrochelids associated with manure and coprid beetles in Israel. I. Macrocheles robustulus (Berleses, 1904), development and biology. Acarologia 8, 532-548.

Costa, M., 1967. Notes on macrochelids associated with manure and coprid beetles in Israel. II. Three new species of the Macrocheles pisentii complex, with notes on their biology. Acarologia 9, 304-329.

Christmas, P.E., 1970. Laboratory rearing of the biting fly Stomoxys calcitrans (Diptera: Muscidae). N. Z. Entomol. 4, 446-449.

Dominghetti, T.F.S., Barros, A.T.M., Soares, C.O., Cançado, P.H.D., 2015. Stomoxys calcitrans (Diptera: Muscidae) outbreaks: current situation and future outlook with emphasis on Brazil. Rev. Bras. Parasitol. Vet. 24, 387-395.

Doube, B.M., Macqueen, A., Huxham, K.A., 1986. Aspects of predatory activity of Macrocheles peregrinus (Acarini: Acrochelidae [sic]) on two species of Haematobia fly (Diptera: Muscidae). In: Patterson, R.S., Rutz, D.A. (Eds.), Biological Control of Muscoid Flies. Entomological Society of America, Miscellaneous Publications,
Gainesville, pp. 132-141

Elkan, P.W., Parnell, R., Smith, D., 2009. A die-off of large ungulates following a Stomoxy biting fly out-break in lowland forest, northern Republic of Congo. Afr. J. Ecol. 47, 528-536.

Enkegaard, A., Sardar, M.A., Brødsgaard, H.F., 1997. The predatory mite Hypoaspis miles: biological and demographic characteristics on two prey species, the mushroom sciarid fly, Lycoriella solani, and the mould mite, Tyrophagus putrescentiae. Entomol. Exp. Appl. 82, 135-146.

Filipponi, A., Delupis, G.D., 1963. Sul regime dietetico di alcuni Macrochelidae (Acari: Mesostigmata), associati in natura a muscidi di interesse sanitario. Riv. Parassitol. 24, 277-287.

Filipponi, A., Mosna, B., 1968. Influenza di fattori ecologici e genetici sulla natalità e mortalità di Macrocheles robustulus (Berlese, 1904). Ann. Int. Super. Sanità. 4, $551-571$.

Fosbrooke, H.A., 1963. The Stomoxys plague in Ngorongoro, 1962. Afr. J. Ecol. 1, $124-126$.

Furtado, I.P., Moraes, G.J., Kreiter, S., Tixier, M.S., Knapp, M., 2007. Potential of a Brazilian population of the predatory mite Phytoseiulus longipes as a biological control agent of Tetranychus evansi (Acari: Phytoseiidae, Tetranychidae). Biol. Control 42, 139-147.

Gerson, U., Smiley, R., Ochoa, R., 2003. Mites (Acari) for Pest Control. Blackwell Science, Oxford.

Guanilo, A., Cordero, J., 2003. Comportamiento depredador de Macrocheles muscaedomesticae (Scopoli) (Acarina: Macrochelidae) sobre huevos de Musca domestica Linnaeus (Diptera: Muscidae). Rev. Peruana Entomol. 43, 137-142.

Halliday, R.B., Holm, E., 1987. Mites of the family Macrochelidae as predators of two species of dung-breeding pest flies. Entomophaga 32, 333-338.

Herrero, M.V., Montes, L., Sanabria, C., Sánchez, A., Hernández, R., 1989. Estudio inicial sobre la mosca de los establos Stomoxys calcitrans (Diptera: Muscidae), en la región del pacífico sur de Costa Rica. Cienc. Vet. 11, 11-14.

Ho, C.C., 1989. Studies on the biology of Macrocheles muscaedomesticae (Scopoli) (Acarina: Macrochelidae). Chin. J. Entomol. 3, 181-187.

Ito, Y., 1973. The effects of nematode feeding on the predatory efficiency for house fly eggs and reproduction rate of Macrocheles muscaedomesticae (Acarina: Mesostigmata). Jpn. Soc. Med. Entomol. Zool. 23, 209-213.

Kinn, D.N., 1966. Predation by the mite, Macrocheles muscaedomesticae (Acarina: Macrochelidae), on three species of flies. J. Med. Entomol. 3, 155-158.

Koller, W.W., Catto, J.B., Bianchin, I., Soares, C.O., Paiva, F., Tavares, L.E.R., Graciolli, G. 2009. Surtos da Mosca-dos-estábulos, Stomoxys calcitrans, em Mato Grosso do Sul: Novo Problema para as cadeias Produtivas da Carne e Sucroalcooleira? Embrapa Documentos 175. $31 \mathrm{p}$

Krantz, G.W., 1983. Mites as biological control agents of dung-breeding flies, with special reference to Macrochelidae. In: Hoy, M.A., Cunngham, G.L., Knutson, L. (Eds.), Biological Control of Pests by Mites. University of California, Berkeley, pp. 91-98.

Legner, E.F., 1995. Biological control of Diptera of medical and veterinary importance. J. Vector. Ecol. 20, 59-120.

Lindquist, E.E., Krantz, G.W., Walter, D.E., 2009. Order Mesostigmata. In: Krantz, G.W., Walter, D.E. (Eds.), A Manual of Acarology. Texas Tech University Press, Lubbock, pp. 124-232.

Maia, A.H.N., Luiz, A.J.B., Campanhola, C., 2000. Statistical inference on associated fertility life table parameters using jackknife technique: computational aspects. J. Econ. Entomol. 93, 511-518.

Maia, A.H.N., Luiz, A.J.B., 2006. Programa SAS para análise de tabelas de vida e fertilidade de artrópodes: o método Jackknife. Embrapa (Comunicado técnico), vol. 33, $1-11$.

Malik, A., Singh, N., Satya, S., 2007. House fly (Musca domestica): a review of control strategies for a challenging pest. J. Environ. Sci. Health B 42, 453-469.

Mariconi, F.A.M., Guimarães, J.H., Berti Filho, E., 1999. A mosca doméstica e algumas outras moscas nocivas. FEALQ, Piracicaba.

Marquardt, T., Kaczmarek, S., Halliday, B., 2015. Ovoviviparity in Macrocheles glaber (Müller) (Acari: Macrochelidae), with notes on parental care and egg cannibalism. Int. J. Acarol. 41, 71-76.

Massaro, M., Martin, J.P.I., Moraes, G.J., 2016. Factitious food for mass production of predaceous phytoseiid mites (Acari: Phytoseiidae) commonly found in Brazil. Exp. Appl. Acarol. 70, 411-420.

McMurtry, J.A., Sourassou, N.F., Demite, P.R., 2015. The Phytoseiidae (Acari: Mesostigmata) as biological control agents. In: Carrilo, D., Moraes, G.J., Peña, J. (Eds.), Prospects for Biological Control of Plant Feeding Mites and Other Harmful Organisms. Springer International Publishing, Switzerland, pp. 133-149.

Mora, S.T., Calvache, H.G., Alvañil, F.A., Torres, A.J., Verdugo, A., Luna, J.E., 1997. La mosca de los establos Stomoxys calcitrans (L.) (Diptera: Muscidae), en palma de aceite. Palmas 18, 31-42.

Moreira, G.F., Moraes, G.J., 2015. The potential of free living laelapid mites (Mesostigmata: Laelapidae) as biological control agents. In: Carrilo, D., Moraes, G.J., Peña, J. (Eds.), Prospects for Biological Control of Plant Feeding Mites and Other Harmful Organisms. Springer International Publishing, Switzerland, pp. 77-102.

Moreira, G.F., Morais, M.R., Busoli, A.C., Moraes, G.J., 2015. Life cycle of Cosmolaelaps jaboticabalensis (Acari: Mesostigmata: Laelapidae) on Frankliniella occidentalis (Thysanoptera: Thripidae) and two factitious food sources. Exp. Appl. Acarol. 65, 219-226.

Perotti, M.A., 2001. Prey location and predation rates of predatory mites (Acari: Macrochelidae) on immature stages of pest flies (Diptera: Muscidae). Syst. Appl. Acarol. 6, 27-33.

Pruett, J.H., Steelman, C.D., Miller, J.A., Pound, J.M., George, J.E., 2003. Distribution of horn flies on individual cows as a percentage of the total horn fly population. Vet. Parasitol. 116, 251-258. 
Ragusa, S., Zedan, M.A., 1988. Biology and predation of Hypoaspis aculeifer (Canestrini) (Parasitiformes, Dermanyssidae) on Rhizoglyphus echinopus (Fum. \& Rob.) (Acariformes, Acaridae). Giornale di Entomologia, Redia, pp. 213-225.

Rodrigues, J.G., Wade, C.F., Wells, C.N., 1962. Nematodes as natural food for Macrocheles muscaedomesticae (Acarina: Macrochelidae), a predator of the house fly egg. Ann. Entomol. Soc. Am. 55, 507-511.

Sabelis, M.W., 1985. Capacity for population increase. In: Helle, W., Sabelis, M.W. (Eds.), Spider Mites: Their Biology, Natural Enemies and Control. Elsevier, World Crop Pests, Netherland, pp. 35-42.

Singh, P., King, W.E., Rodriguez, J.G., 1966. Biological control of muscids as influenced by host preference of Macrocheles muscaedomesticae (Acarina: Macrochelidae). J. Med. Entomol. 3, 78-81.

Skovgård, H., Nachman, G., 2004. Biological control of house flies Musca domestica and stable flies Stomoxys calcitrans (Diptera: Muscidae) by means of inundative releases of Spalangia cameroni (Hymenoptera: Pteromalidae). Bull. Entomol. Res. 94, 555-567. Soliman, Z.R., Zaher, M.A., Mohamed, M.I., 1978. Biology and predaceous efficiency of Macrocheles matrius Hull Acari, Mesostigmata. Z. Angew. Entomol. 85, 225-230.

Tayeh, A., Estoup, A., Lombaert, E., Guillemaud, T., Kirichenko, N., Lawson-Handley, L., Clercq, P., Facon, B., 2014. Cannibalism in invasive, native and biocontrol populations of the harlequin ladybird. BMC Evol. Biol. 14, 1-9.

Wade, C.F., Rodriguez, J.G., 1961. Life history of Macrocheles muscaedomesticae (Acarina: Macrochelidae), a predator of the house fly. Ann. Entomol. Soc. Am. 54, 776-781.

Wright, E.M., Chambers, R.J., 1994. The biology of the predatory mite Hypoaspis miles (Acari: Laelapidae), a potential biological control agent of Bradysia pauper (Diptera: Sciaridae). Entomophaga 39, 225-235. 